\title{
EUTANAZJA A PRAWO DO ŻYCIA. FILOZOFICZNY SPÓR O ZAKRES OBOWIĄZYWANIA NORMY „NIE ZABIJAJ”
}

Stowa klucze:

eutanazja, prawo do śmierci, eutanazja bierna, eutanazja czynna

\section{Treść:}

I. Pojęcie i rodzaje eutanazji

II. Argumentacja antropologiczna

III. Respekt dla autonomii człowieka

IV. Obiektywna moralna nienaruszalność ludzkiego życia

V. Prawo do dobrowolności decyzji

VI. Argument z tak zwanej ,równi pochyłej”

VII. Argumentacja religijna

VIII. Argument odwołujący się do społecznych opinii

W marcu 2005 roku cały świat obiegła dramatyczna wiadomość o umierającej z głodu i pragnienia Terri Schiavo, która przez 15 lat pozostawała w tzw. stanie wegetatywnym z częściowo obumarłym mózgiem. Ta 47-letnia kobieta, która po nagłym zawale serca zapadła w śpiączkę, została decyzją Sądu Najwyższego USA odłączona od aparatury podtrzymującej życie. Mimo kilkutygodniowej batalii o jej życie, którą toczyli obrońcy życia, nie udało się uratować tej kobiety. Prawo do jej śmierci wywalczył mąż chorej, mimo mocnego sprzeciwu jej rodziców, którzy nie dopuszczali myśli, że ich córka mogłaby zgodzić się na taką ewentualność. Niespełna trzy lata później podobna dyskusja na temat prawa do śmierci rozpaliła Włochy. Po 17 latach przebywania w stanie wegetatywnym Eluany Englaro sąd wydał zgodę na odłączenie sondy dostarczającej jej pożywienie. Oponentem wyroku był między innymi rząd Silvia Berlusconiego. Wydał on dekret odmawiający lekarzom prawa do wykonania takich czynności. Decyzję jednak zablokował prezydent Giorgio Napolitano. Kilka dni później kobieta zmarła.

${ }^{*}$ Ks. Daniel Bubula, mgr lic. teologii, mgr filozofii, doktorant filozofii na KUL. 
Na początku XXI wieku precedensy te jeszcze raz ożywiły dyskusję na temat uprawnień do podejmowania decyzji o życiu człowieka. Zagadnienie eutanazji spotyka się z coraz większym zainteresowaniem opinii publicznej, wywołując przy tym wiele emocji. Wspomniane wcześniej przypadki uświadamiają nam, iż każdy z nas może znaleźć się w podobnej sytuacji. Dlatego też poważna refleksja nad tym problem nie jest jedynie moralnym zobowiązaniem wobec osób znajdujących się w tak dramatycznej sytuacji, ale przede wszystkim wyrazem troski o nas samych. Nic więc dziwnego, że problem ten staje się przedmiotem zainteresowań wielu dziedzin nauki, które w sposób dla siebie właściwy badają i analizują kwestię eutanazji. Na problem eutanazji można przecież spojrzeć wieloaspektowo. Tym jednak, co wyróżnia w tych dyskusjach filozofa, etyka, jest próba poszukiwania rozumowych racji, dla których eutanazję można uznać, bądź też nie, za moralnie usprawiedliwioną. Nie ulega wątpliwości, że pytanie o moralną dopuszczalność eutanazji jest jednym z tych dylematów, na które istnieje odpowiedź „tak” lub „nie”. Stąd tak ważne jest, aby była ona udzielana na podstawie dogłębnego, rzeczowego przemyślenia argumentów przytaczanych na rzecz każdej z opcji. Moim celem jest przybliżenie podstawowych pojęć i sposobów argumentacji $\mathrm{w}$ dyskusji nad eutanazją szczególnie tym, których interesuje wypracowanie własnego poglądu w tej kwestii. Dlatego też po wstępnym przyjrzeniu się pojęciu i rodzajom eutanazji, przeanalizujemy główne argumenty przytaczane zarówno przez jej zwolenników, jak i przeciwników. Dotyczą one między innymi różnych koncepcji osoby, odmiennego rozumienia autonomii ludzkiej, prawa do dobrowolności decyzji, czy też zarzutu tzw. „równi pochyłej”. Są wśród nich także argumenty religijne oraz te odwołujące się do społecznych opinii.

\section{POJĘCIE I RODZAJE EUTANAZJI}

Pojęcie eutanazji stało się bardzo wieloznaczne. Ujawnia to już samo zróżnicowanie terminów. Mówi się o eutanazji, kryptanazji, autotanazji, dystanazji, zabójstwie z litości czy o pomocy w umieraniu itd. W naszych rozważaniach nie wydaje się jednak celowe koncentrowanie się na problemach definicyjnych, tym bardziej, że zakres tego pojęcia pozostaje nieostry, a w wielu wypadkach sporny. Niemniej jednak trzeba zauważyć, iż termin „eutanazja” wiąże się ściśle z kontekstem medycznym. Problem eutanazji to problem moralnej oceny działania polegającego na pomaganiu drugim w odejściu z tego świata. Dramatem jest spełnianie takich próśb, albowiem niezależnie od tego, jakie intencje będą im towarzyszyły, zawsze będzie tu ktoś, kto jest zabijany i ktoś, kto zabija ${ }^{1}$. Biorąc za kryterium sposób, w jaki sprawca pomaga odejść pacjentowi, działania eutanatyczne dzielą się na czynne i bierne. Przenosząc to na pole etyki, będzie to zabójstwo przez dzia-

\footnotetext{
${ }^{1}$ Por. B. Chyrowicz, Eutanazja i spór o argumenty, w: Eutanazja: Prawo do życiaprawo do wolności, red. B. Chyrowicz, Lublin 2005, s. 161.
} 
łanie (eutanazja czynna) oraz przez jego zaniechanie (eutanazja bierna). Pierwszy rodzaj eutanazji będzie polegać na podaniu przez lekarza wprost letalnego środka pacjentowi, drugi zaś jest sytuacją, w której lekarz celowo nie podaje pacjentowi koniecznych do przeżycia środków i tym samym przyśpiesza jego śmierć ${ }^{2}$. W przypadku eutanazji biernej chodzi o te wszystkie przypadki, w których lekarz nie podejmuje czynności mogących zapobiec śmierć pacjenta lub ją opóźnić. W efekcie śmierć jest bezpośrednio następstwem choroby, a nie skutkiem jakieś interwencji medycznej ${ }^{3}$. Do tego rodzaju eutanazji zalicza się także sytuacje, w których lekarz zaprzestaje sztucznego podtrzymywania pacjenta przy życiu przez odłączenie respiratora, sondy dostarczającej mu pożywienie, czy też innej aparatury podtrzymującej funkcje życiowe. Biorąc pod uwagę zewnętrzny przebieg działania, można sądzić, że eutanazja bierna niczym nie różni się od rezygnacji z uporczywej terapii. W medycynie sytuacje te różnicuje się przez podział na zwyczajne środki ratowania życia oraz tzw. uporczywą terapię ${ }^{4}$. Nawet radykalni przeciwnicy eutanazji nie posuwają się do żądania ratowania życia w każdych okolicznościach, niezależnie od możliwości przewidzenia szans powodzenia dostępnych metod terapeutycznych ${ }^{5}$. Tym, co różnicuje eutanazję bierną od rezygnacji $z$ uporczywej terapii, jest stan pacjenta (uleczalny bądź nieuleczalny) i powód zaprzestania działań terapeutycznych (rezygnacja z uporczywej terapii bądź przyspieszenie śmierci pacjenta). Decyzja o tym, czy da się pacjenta wyleczyć, czy też nie, leży w kompetencji lekarza. Wobec tego nieprzystąpienie do tego rodzaju „nadzwyczajnej” terapii lub jej przerwanie nie jest traktowane jako bierna eutanazja, a jedynie jako wyraz bezradności medycyny. W etyce mówi się wtedy o tzw. dystanazji. Skutek jest ten sam, ale nie ma intencji eutanatycznej. Jednakże trzeba mieć świadomość, iż granica, między terapią zwykłą a uporczywą jest nieostra. Rozróżnienie dokonywane jest przez lekarza na podstawie oceny stanu danego pacjenta i realnie dostępnych metod leczenia. Skoro każdą bezskuteczną terapię trzeba przerwać, to z punktu widzenia kwalifikacji postępowania lekarza ważny jest motyw jej przerwania. Eutanazja bierna jest zwykle rozumiana jako rezygnacja $\mathrm{z}$ dalszego leczenia lub przedłużania życia chorego. Może ona mieć przy tym charakter dobrowolny, wtedy gdy dochodzi do niej w wyniku woli samego pacjenta. Szczególnie trudne problemy wiążą się z pytaniem, na ile tę decyzję o zakończeniu życia można uznać za wyraz jego rzeczywistej woli. A więc na ile są one świadome i dobrowolne oraz przemyślane i ostateczne. Odrębne pytania wiążą się z eutanazją niedo-

${ }^{2}$ Por. H. Kuse, Eutanazja, w: Przewodnik po etyce, red. P. Singer, Warszawa 1998, s. 339-340.

${ }^{3}$ Por. B. Chyrowicz, Eutanazja i spór o argumenty, dz. cyt., s. 162.

${ }^{4}$ Por. T. Pietrzykowski, Spór o eutanazję. Etyczne problemy prawa, Katowice 2007, s. 33.

${ }^{5}$ Por. C. Bernard, Od biologii do etyki. Nowe horyzonty wiedzy. Nowe obowiazki człowieka, tłum. J. Żelechowska, Warszawa 1994, s. 48-49. 
browolną, która następuje w sytuacji, kiedy sam pacjent nie zdążył wyrazić żadnego życzenia ${ }^{6}$. Kto więc ma prawo $\mathrm{w}$ jego imieniu do podejmowania takich decyzji? Decyzje te są w tym sensie nieuniknione, że w jakiś sposób trzeba postępować wobec osób znajdujących się w takiej sytuacji. Eutanazja bierna miałaby więc miejsce w sytuacji, w której pacjent oczekuje kontynuowania terapii. Choć słusznie zwraca się uwagę, że eutanazja tego typu jest zabójstwem przez zaniechanie, to sprawa się nieco komplikuje z powodu realnie istniejącego problemu nieostrości granic uporczywości terapeutycznej. Poszczególni lekarze między sobą mogą się różnić w ocenie, czy istnieje jeszcze jakaś realna możliwość pomocy choremu. Przykładem biernej eutanazji może być też rezygnacja z leczenia noworodka, kiedy terapia taka jest możliwa i przynosi efekty. W odróżnieniu od eutanazji biernej tzw. eutanazja czynna nie polega na dopuszczeniu do śmierci pacjenta wskutek zaniechania czy przerwania stosownej wobec niego terapii, ale na aktywnym spowodowaniu przez lekarza jego śmierci. A to może mieć miejsce w dwóch przypadkach. Pośrednio wtedy, kiedy ciężko choremu podajemy środki uśmierzające tego rodzaju i w takiej ilości, że ich skutkiem ubocznym jest wcześniejsza śmierć. Przypomnijmy, że celem działania lekarza powinno być w tej sytuacji przyniesienie ulgi cierpiącej osobie. Dopuszczalność takiego działania jest usprawiedliwiona tzw. zasadą podwójnego skutku ${ }^{7}$. Lekarz nie zmierza do tego, aby spowodować śmierć pacjenta, lecz do tego, aby złagodzić jego cierpienie, zdając sobie sprawę, że prawdopodobnym efektem ubocznym może być przyspieszenie zgonu. Oczywiście warunkiem usprawiedliwiającym takie działanie jest barak jakiejkolwiek innej możliwości ulżenia cierpieniom pacjenta. Co więcej, musi ono być pozbawione najistotniejszego negatywnego elementu eutanazji czynnej, czyli intencji eutanatyczej ${ }^{8}$. Przez eutanazję czynną bezpośrednią rozumiemy czyn lekarza polegający na świadomym uśmierceniu pacjenta. W praktyce najczęściej chodzi o podanie terminalnie i nieuleczalnie chorym środków mających spowodować ich szybki i bezbolesny zgon. Podobnie jak w przypadku eutanazji biernej, również tutaj można wyróżnić eutanazję dobrowolną, niedobrowolna i przymusową ${ }^{9}$.

Za działanie o charakterze eutanatycznym należałoby uznać też pomoc pacjentowi $\mathrm{w}$ samobójstwie. $\mathrm{W}$ tym wypadku pacjent zarówno podejmuje decyzję o zakończeniu życia, jak i wprowadza ją w czyn ${ }^{10}$. Może to mieć miejsce wtedy, gdy pacjentowi zostaje udostępniony za jego wyraźną zgodą

\footnotetext{
${ }^{6}$ Por. W. Wichrowski, W. Jacórzyński, Spór o eutanazję, „Medicus” 1992, s. 18.

${ }^{7}$ Zasada ta odwołuje się do działań, z których równocześnie mogą wyniknąć dwa rodzaje skutków: dobre i złe. Określa ona też warunki, by można było usprawiedliwić zły skutek wynikający z takich działań. Najpierw samo działanie powinno mieć znamiona moralnej słuszności. Dalej zamierzonym skutkiem działania jest skutek dobry, zły jest przewidywany, ale niezamierzony. Działanie musi być proporcjonalne do celu.

${ }^{8}$ Por. T. Pietrzyk owski, Spór o eutanazję, dz. cyt., s. 39-41.

${ }^{9}$ Por. W. Wichrowski, W. Jacórzyński, Spór o eutanazję, dz. cyt., s. 18-19.

${ }^{10}$ Por. T. Ślipko, Granice życia: dylematy wspótczesnej bioetyki, Warszawa 1988, s. 261.
} 
śmiercionośny środek, a on sam decyduje, czy z niego skorzysta. Pomoc w samobójstwie znacznie ogranicza udział służby zdrowia w „odejściu” pacjenta. Za samobójstwo nikogo się nie karze. Cała więc procedura mogłaby się wydawać bezkarna, gdyby nie fakt, że udostępnienie pacjentowi letalnego środka jest formą współudziału w złu, jakim jest samobójstwo. Żeby oskarżyć kogoś o współudział, to trzeba najpierw uznać samobójstwo za zło, a następnie umiejętnie wykazać istniejący związek pomiędzy działaniem pacjenta a działaniem współuczestniczącego. Związek ten może mieć charakter zarówno materialny, kiedy lekarz działa nieświadomie, jak i formalny. W tym ostatnim przypadku oprócz materialnego działania dochodzi także intencyjne zaangażowanie się w przebieg samobójstwa. Takie zaangażowanie lekarza czyni go współwinnym i współodpowiedzialnym za śmierć pacjenta, przy założeniu, że samobójstwo jest złem ${ }^{11}$.

\section{ARGUMENTACJA ANTROPOLOGICZNA}

Długotrwała oraz pełna emocji debata nad dopuszczalnością eutanazji tak na prawdę jest sporem o rozumienie ludzkiego życia oraz o sens cierpienia i śmierci. Argumentacja $\mathrm{w}$ dyskutowanym tutaj problemie pozostaje powiązana z przyjmowaną koncepcją człowieka, z koncepcją osoby ${ }^{12}$. Według antropologii personalistycznej wsobna wartość osoby, jej godność, jest jej dana $\mathrm{z}$ natury wraz z zaistnieniem. To nie uposażenie biologiczne, genetyczne, psychiczne, intelektualne nadaje wartość osobie, lecz odwrotnie. W tej perspektywie wszyscy są równi. Życie człowieka pełnosprawnego czy niepełnosprawnego, zdrowego czy umierającego jest tak samo wartościowe. Stąd afirmacja godności osoby jest podstawą wszelkich moralnych zachowań. Zwolennicy eutanazji, podobnie jak zwolennicy selekcji prenatalnej, odwracają ten porządek. Status osoby uzależniają od pewnych jakościowych kryteriów, takich jak świadomość, zdolność do zadbania o swoje potrzeby, a przynajmniej do zapewnienia sobie minimalnej niezależności w zakresie ubierania się, zachowania higieny osobistej i spożywania posiłków. Kto nie spełnia tych kryteriów, pozbawiony jest miana podmiotu, osoby, pozbawiony jest także prawa do życia. Za wartościowe można uznać według nich tylko takie życie, któremu towarzyszy określona kondycja psychofizyczna. $\mathrm{Z}$ chwilą, gdy teoria nie ustala $\mathrm{z}$ góry jakościowych kryteriów wartościowego życia, wartość ta zostaje wyznaczona subiektywnie. Na podstawie takich teorii należałoby konsekwentnie uznać, że nie tylko eutanazja dobrowolna, ale w pewnych szczególnych przypadkach (np. ciężka choroba psychiczna, stan śpiączki) również eutanazja niedobrowolna winna zostać usprawiedliwiona $^{13}$. W ten sposób obrońcy eutanazji, tworząc deskryptywną koncepcję

\footnotetext{
${ }^{11}$ Por. B. Chyrowicz, Eutanazja i spór o argumenty, dz. cyt., s. 162-163.

${ }^{12}$ Por. H. Ni emi ec, Życie, cierpienie, śmierć a eutanazja, w: Eutanazja a opieka paliatywna. Aspekty etyczne, religijne, psychologiczne i prawne, red. A. Bi ela, Lublin 1996, s. 77.

${ }^{13}$ Por. Chrześcijanin wobec eutanazji, red. K. Gryz, B. Mielec, Kraków 2001, s. 14.
} 
osoby, dokonują podwójnego uśmiercania człowieka: najpierw jako osoby, a później samego organizmu. Zastosowana w praktyce zasada ,jakości życia” staje się kryterium podziału na tych, których ,życie jest warte życia” i tych, których „życie jest niewarte życia"14. Odpierając ten zarzut, zwolennicy eutanazji przyjmują dwie strategie. Jedni, jak Peter Singer, otwarcie przyznają, że idea eutanazji opiera się na etyce jakości życia, która powinna zastąpić tradycyjną etykę świętości życia. Stanowi to jego zdaniem jedyną możliwą, pozbawioną hipokryzji odpowiedź na dylematy moralne współczesności ${ }^{15}$. W rzeczywistości chodzi zatem o zróżnicowanie wartości życia poszczególnych osób, gdyż niektóre z nich uznaje się za mniej warte życia, dlatego też $\mathrm{w}$ stosunku do nich eutanazja byłaby dopuszczalna. Drudzy twierdzą, iż postulat równego traktowania życia i bezwzględny zakaz jego wartościowania jest głęboko sprzeczny $\mathrm{z}$ najbardziej elementarnymi intuicjami moralnymi oraz samą instytucją medycyny i leczeniem pacjentów ${ }^{16}$. Pozostaje jedynie pytanie kto i kiedy może tego rodzaju wartościowania dokonywać (sam chory czy inne osoby). Przeciwnicy eutanazji wskazują jednak, że ocena wartości życia przez chorych zależy w dużej mierze od tego, w jakich warunkach ma być ono kontynuowane. Zamiast legalizacji eutanazji postulują zapewnienie pacjentom odpowiedniego poziomu opieki paliatywnej przez promowanie ruchu hospicyjnego. Podkreśla się przy tym, że nie zdarza się, aby pacjenci otoczeni troską i opieką na odpowiednim poziomie formułowali prośby o eutanazję ${ }^{17}$.

\section{RESPEKT DLA AUTONOMII CZŁOWIEKA}

Najbardziej podstawowym argumentem, jaki przytacza się w sporze o legalizację eutanazji dobrowolnej, jest respekt dla autonomii osoby ludzkiej co do decyzji o przebiegu i zakończeniu przez nią życia. Skoro człowiek ma prawo, a nie obowiązek do życia, to $\mathrm{z}$ tego prawa może dobrowolnie zrezygnować. Dlatego nie można zaakceptować roszczeń osób trzecich do decydowania za cierpiących w takiej sytuacji. Co więcej, nie można w imię jakiejś abstrakcyjnej wartości zmuszać za pomocą prawa kogokolwiek, a zwłaszcza ciężko i nieuleczalnie chorych pacjentów, do bezcelowego znoszenia cierpień ponad siły. Ten argument $\mathrm{z}$ autonomii jednostki ma $\mathrm{w}$ debacie szczególną siłę, albowiem wolność podejmowania samodzielnych decyzji o swoim losie rzadko bywa kwestionowana. Mało tego, istnieje powszechna zgoda, co do negatywnej oceny cierpień i bólu wynikających z choroby. Spór dotyczy tu zatem granic owej autonomii, a nie samego obowiązku jej poszanowania. Głębsza refleksja nad tym prowadzi do stwierdzenia, iż wolność nie obejmuje decyzji

\footnotetext{
${ }^{14}$ Por. P. Morciniec, Etyczne aspekty transplantacyjnej terapii chorób neurozwyrodnieniowych, Opole 2000, s. 178.

${ }^{15}$ Por. T. Pi etrzyk ow ski, Spór o eutanazję, dz. cyt., s. 98.

${ }^{16}$ Por. tamże, s. 101.

${ }^{17}$ Por. J. Dziedzic, Spór o eutanazję, Kraków 2005, s. 79-81.
} 
zmierzających do unicestwienia samego siebie. Życie bowiem stanowi warunek wolności, a decyzja o jego zakończeniu oznaczałaby utratę także tej wartości. Dlatego zasada ta nie powinna chronić decyzji o unicestwieniu życia jednostki, stanowiącego przecież podstawowy warunek korzystania przez nią $\mathrm{z}$ wolności ${ }^{18}$. Przeciwnicy eutanazji posługują się tu także argumentem konsekwencji, albowiem przyjęcie tezy o prymacie wolności jednostki nad wartością jej życia powoduje, że prawo do eutanazji czynnej mają nie tylko cierpiący, ale i znudzeni życiem. Co więcej, jeden z kluczowych argumentów zwolenników eutanazji pomija również nacisk psychologiczny, jakiemu podlegają chorzy w chwili podejmowania decyzji. Decyzje osób domagających się pomocy lekarzy w pozbawieniu życia często wynikają ze szczególnego stanu emocjonalnego, który u licznych jest stanem spełniającym wszystkie kryteria diagnostyczne depresji. Dlatego to zniechęcenie nie jest cechą trwałą i u wielu osób przemija ${ }^{19}$. B. Chyrowicz, analizując ten argument, rozróżnia między „wartością ludzkiego życia” a „wartością mojego życia”. Przez to pierwsze określenie rozumie wartość ludzkiego życia ujętą abstrakcyjnie, nieodniesioną do konkretnego podmiotu. Zdaniem większości autorów współczesnych opowiadających się za usprawiedliwieniem niektórych przypadków eutanazji, działania takie jakoś można by moralnie usprawiedliwić na podstawie indywidualnej decyzji podmiotu stwierdzającego, iż „,moje życie” jest już nic niewarte. To, iż uznaję moje życie za pozbawione wartości, wcale nie implikuje twierdzenia, że ludzkie życie jako takie jest pozbawione sensu. Stąd próby samobójstwa wydają się zrozumiałe tylko dla ofiary. Dla niej jawią się jako jedyne racjonalne rozwiązanie. Obserwatorom zaś taka desperacka decyzja wydaje się niepojęta. To pytanie o wartość mojego życia w dyskusji na temat eutanazji powraca. Godząc się bowiem na dobrowolną eutanazję, przyzwalamy na to, iż człowiek, ze swej natury wolny, ma prawo taką decyzję podjąć. A my szanując ją, pomagamy mu w „odejściu”20. Według B. Chyrowicz nie jest paradoksem to, iż przytłoczony ciężkim cierpieniem człowiek uznaje swoje życie za pozbawione wartości, a jednocześnie nie przeczy wartości życia jako takiego. Ostatecznie w tej dramatycznej sytuacji jedni nadal będą widzieć sens życia, inni nie. W kontekście eutanazji problem sensu życia nieuchronnie wiąże się z pytaniem o sens cierpienia. A na to pytanie nikomu jeszcze w kontekście pozareligijnym nie udało się znaleźć teoretycznej odpowiedzi. Problemu cierpienia bowiem nie da się zracjonalizować. Próby odpowiedzi dotyczą tu zasadniczo sensu doświadczanego przez jednostkę cierpienia, a nie cierpienia jako takiego. Koncentrowanie się na pytaniu o sens ,,mojego życia” sprawia, że nasza dyskusja może utknąć w martwym punkcie. Stąd w powyższej debacie powinniśmy raczej skupić się na pytaniu o wartość życia jako taką (in abstracto). Tylko takie podejście umożliwia racjonalny dyskurs ${ }^{21}$.

\footnotetext{
${ }^{18}$ Por. T. Pietrzykowski, Spór o eutanazję, dz. cyt., s. 84-87.

${ }^{19}$ Por. S. Pużyński, Psychiatra i eutanazja, „Dialog” 9(2000), s. 54.

${ }^{20}$ Por. B. Chyrowicz, Eutanazja $i$ spór o argumenty, dz. cyt., s. 145-147.

${ }^{21}$ Por. tamże, s. 148 .
} 


\section{OBIEKTYWNA MORALNA NIENARUSZALNOŚĆ LUDZKIEGO ŻYCIA}

Nieograniczonej autonomii jednostki przeciwstawia się „obiektywna moralna nienaruszalność ludzkiego życia"22. Życie ludzkie stanowi wartość absolutną, a nakaz „nie zabijaj” zyskuje status normy bezwzględnej i niepozostającej w dyspozycji osób, które dotyczy. Uznanie ludzkiego życia za dobro nie wiąże się z uznaniem go za najwyższą wartość. Życie jest nie tyle największą z możliwych wartości, ile wartością fundamentalną. Dlatego też nie wolno jej naruszać zarówno w stosunku do siebie, jak i do innych. Stąd akty poświęcenia swojego życia za innych (etyka tomistyczna, fenomenologiczna etyka Dietricha von Hildebranda) są wyrazem istnienia wartości większych niż życie. Inaczej jest w przypadku samobójcy. On decyduje, że lepsze jest nieistnienie niż istnienie pełne cierpienia. Jednak ostatecznie za utraconą wartością życia nie stoi żaden ekwiwalent ${ }^{23}$. Sytuacja wydaje się asymetryczna: istnieją większe dobra niż istnienie, ale nie istnieje większe zło niż nieistnienie. Ta asymetria znika jednak, kiedy weźmiemy właściwą antropologię. Życie człowieka nie wyczerpuje się na poziomie biologii. Kiedy ktoś poświęca swoje życie w obronie własnych przekonań, czyni tak w przeświadczeniu, że ginąc, ratuje zarazem własne życie w innym wymiarze (zdrada samego siebie byłaby rodzajem duchowego samobójstwa). Wynika więc stąd, że eutanazja jest kontrowersyjna $\mathrm{z}$ uwagi na to, iż ,życie ludzkie jako takie" nie jest tylko życiem biologicznym ${ }^{24}$. Przeciwnik eutanazji podkreślać będzie fundamentalny charakter wartości istnienia, wskazując na ontyczną zależność jakości życia od samego istnienia. Dlatego też będzie bronił nienaruszalności ludzkiego życia, powołując się na wyjątkowość jego istnienia. Niemniej jednak niepowtarzalności tej winniśmy szukać nie tyle w wymiarze czysto biologicznym, ile przez odwołanie się do cech rozumności i wolności, które są właściwe tylko człowiekowi. Skoro to życie biologiczne przedstawia jakąś wartość, to wynika stąd, iż nie należy go tak diametralnie w sposób celowy kończyć. Ta prawda może stanowić argument przeciw eutanazji. Skrócenie życia będzie złem nie tylko naturalnym, lecz także moralnym.

Teoretyczne przekonania nie przekładają się tak łatwo na praktykę, jakbyśmy sobie tego życzyli. Problematyczny okazuje się bowiem zakres obowiązywania normy „nie zabijaj”, a nie sama norma jako taka. Przeciwnik eutanazji będzie zawsze oceniał zło pomocy w samobójstwie i eutanazji jako zło zabijania, albowiem jest ono związane $\mathrm{z}$ unicestwieniem drugich. Zło nie tylko naturalne, ale także moralne. Co więcej, w spotkaniu z beznadziejnie chorym przeciwnik eutanazji będzie czekał na naturalny kres życia, pomoże mu uśmierzyć ból, ale nie przyśpieszy nadejścia jego śmierci ${ }^{25}$.

\footnotetext{
${ }^{22}$ Por. T. Ślipko, Zarys etyki szczegółowej. Etyka osobowa, t. 1, Kraków 2005, s. 253.

${ }^{23}$ Por. B. Chyrowi cz, Eutanazja i spór o argumenty, dz. cyt., s. 150-151.

${ }^{24}$ Por. tamże, s. 151.

${ }^{25}$ Por. tamże, s. 153-54.
} 


\section{PRAWO DO DOBROWOLNOŚCI DECYZJI}

Warunkiem dopuszczalności eutanazji dobrowolnej jest dla jej zwolenników wyrażenie przez pacjenta woli w sposób świadomy i nieskrępowany. W tym celu muszą być spełnione trzy warunki. Po pierwsze, chory musi rzeczywiście chcieć tego, co stanowi treść formułowanego przez niego życzenia. Po drugie, pacjent powinien być poinformowany na temat swojej sytuacji i perspektyw zmian. Po trzecie, na chorego nie mogą być wywierane żadne naciski ze strony osób trzecich. Oznacza to, że nie może on pozostawać pod wpływem różnego rodzaju doraźnych impulsów, takich jak np. depresja, atak bólu itp. ${ }^{26}$. Z kolei przeciwnicy eutanazji argumentują, że warunki te budzą poważne wątpliwości. Przede wszystkim poddaje się w wątpliwość, na ile czyjeś życzenie śmierci można w ogóle zinterpretować jako wyraz jego rzeczywistej woli ${ }^{27}$. W większości przypadków jest to przede wszystkim dramatyczna skarga chorego na stan, w którym się znalazł. Adekwatną odpowiedzią powinno być raczej udzielenie mu wsparcia psychicznego i emocjonalnego, zapewnienie opieki i złagodzenie bólu, a nie potraktowanie całej sytuacji, jako pretekstu do tego, aby problem tej osoby rozwiązać w łatwy sposób ${ }^{28}$. Zwolennicy eutanazji zaś widzą $\mathrm{w}$ tym niedopuszczalny przejaw paternalizmu polegającego na tym, że ktoś wie lepiej od samego pacjenta, czego on rzeczywiście pragnie. Ta postawa zakłada bowiem swoisty despotyzm aksjologiczny. Zgadzają się co do tego, aby wprowadzić najbardziej nawet rygorystyczne procedury zabezpieczające pacjenta przed dokonaniem na nim eutanazji, szczególnie w sytuacjach, w których rzeczywiście nie wyraża on takiej woli. Niemniej jednak, jak twierdzą dalej obrońcy eutanazji, pacjent ma prawo do decyzji, którą potrafi racjonalnie uzasadnić, a która jest przemyślanym i ostatecznym wyraz jego woli ${ }^{29}$. Wątpliwości przeciwników eutanazji budzi owa swoboda decyzji podejmowanych przez chorych $\mathrm{w}$ takich sytuacjach ${ }^{30}$. Osoby takie najczęściej doznają poważnych cierpień fizycznych, często zostają poddani długotrwałemu działaniu leków. Ponadto umęczeni psychicznie, zdani na opiekę rodziny, personelu medycznego, mogą mieć zrozumiałą skłonność do postrzegania siebie jako obciążenia dla otoczenia ${ }^{31}$. Świadomość, że istnieje legalne wyjście z tej sytuacji, wywołuje u wielu pacjentów poczucie, że skorzystanie $\mathrm{z}$ niego stanowi, w jakimś sensie, ich powinność wobec innych. To wyimaginowane przekonanie może zwiększać na przykład choćby świadomość kosztów leczenia, jakie

\footnotetext{
${ }^{26}$ Por. T. Pietrzykowski, Spór o eutanazję, dz. cyt., s. 104-105.

${ }^{27}$ Por. N. Aumonier, B. Beiginier, P. Letellier, Eutanazja, thum. E. Burska, Warszawa 2003, s. 23-25.

${ }^{28}$ Por. Chrześcijanin wobec eutanazji, dz. cyt., s. 16.

${ }^{29}$ Por. T. Pietrzyk owski, Spór o eutanazję, dz. cyt., s. 106-107.

${ }^{30}$ Por. J. Keown, Euthanasia, ethics and public Policy. An argument against legalization, Cambridge 2002, s. 56, 73.

${ }^{31}$ Por. E. A. Johnson, Assisted suicide, liberal individualism and visceral jurisprudence. A reply to Professor Chemerinsky, „Alaska Law Review” 20(2003), s. 326-331.
} 
ponosi rodzina ${ }^{32}$. Kolejnym, trzecim warunkiem dobrowolności decyzji, jest podjęcie jej po wszechstronnym zapoznaniu się ze swoją sytuacją zdrowotną. Tu też kryją się pewne trudności. Wielu chorych, których czas życia oceniono zaledwie na kilka dni, żyje po takiej diagnozie jeszcze przez wiele lat. Świadczy to o tym, że wiedza medyczna pozwala ze znacznym marginesem niepewności określić rokowania pacjenta, nie wspominając już, że istotny wpływ na decyzję chorego może mieć sposób przekazania informacji przez lekarza o stanie jego zdrowia. Chory nie jest w stanie zweryfikować sam ich rzetelności. Należy więc unikać sytuacji, w których zostaną mu one przedstawione w sposób sprzyjający podjęciu przez niego niewłaściwej decyzji ${ }^{33}$.

\section{ARGUMENT Z TAK ZWANEJ „RÓWNI POCHYŁEJ”}

Za najpoważniejszy argument przeciwników legalizacji eutanazji uważa się zarzut wkraczania przez jej zwolenników na tzw. ,równię pochyłą”. Chodzi tu o niebezpieczeństwo łatwego przekształcenia praktyki eutanatycznej ze ścisłego wyjątku zastrzeżonego dla sytuacji skrajnych - w dogodną praktykę rozwiązującą przy okazji wiele innych problemów. Żaden zewnętrzny komitet etyczny, oceniający przypadek ex post jedynie na podstawie dokumentów $\mathrm{i}$ informacji otrzymanych od lekarza, nie jest $\mathrm{w}$ stanie prawidłowo zweryfikować stanu, w jakim się pacjent rzeczywiście znajdował. Co więcej, niebezpieczeństwo znalezienia się na „równi pochyłej” można też rozumieć jako ryzyko łatwego przekształcenia legalnej praktyki eutanazji dobrowolnej w ewentualną niedobrowolną, a nawet przymusową. Bierze się ono stąd, iż skoro w przypadku pacjenta mogącego wyrazić swoje życzenia, wolno nam przyjąć, że eutanazja może leżeć w jego najlepszym interesie, to istnieje poważne ryzyko uznania jej za najlepsze rozwiązanie dla osób nieświadomych i upośledzonych $^{34}$. Zamiana ta dotyczy nie tylko kontekstu prawnego, ale także kulturowego i społecznego. Odebranie życia przestaje stanowić problem, a staje się normalnym elementem praktyki medycznej, wymagającym spełnienia jedynie przesłanek ustawowych. Skala zmian w postrzeganiu przez człowieka wartości moralnej życia, a także roli lekarza i jego obowiązków względem pacjenta, pozostaje trudna do przewidzenia. Wkroczenie na eutanatyczną ,równie pochyłą" grozi powrotem nie tylko do praktyki eugenicznej, ,która nie śmie wymówić swego imienia, ale ma już własną przeszłość" 35 , a nawet prowadzi $\mathrm{z}$ powrotem do bram Auschwitz ${ }^{36}$. W odpowiedzi na te obawy zwolennicy eutanazji podnoszą dwa typy argumentów: psychologiczno-logiczne i empiryczne. Przede wszystkim twierdzą, że nie istnieje żaden logiczny związek

\footnotetext{
${ }^{32}$ Por. T. Pietrzyk owski, Spór o eutanazję, dz. cyt., s. 107-108.

${ }^{33}$ Por. tamże, s. 109-110.

${ }^{34}$ Por. tamże, s. 111-113.

${ }^{35}$ J.M. Varault, Możliwe, lecz zakazane. O powinnościach prawa, thum. S. Szwabski, Warszawa 1996, s.105.

${ }^{36}$ Por. W. Grey, Right to die or duty to live? The problem of euthanasia, „Journal of Applied Philosophy" 16(1999), nr 1, s. 24.
} 
zakładający, iż dopuszczenie moralnie pozytywnego czynu doprowadzi do legalizacji czynów moralnie złych. Po to właśnie tworzy się pewne regulacje prawne, aby odróżnić zachowania legalne od nielegalnych. Co więcej, natura człowieka wcale nie jest taka mordercza, jak zakłada strona przeciwna. Legalizacja eutanazji dla osób, które rzeczywiście wyraziły taką wolę, nie prowadzi z konieczności do podobnych działań względem tych, którzy takiego życzenia nie zgłaszają. Zresztą przyznanie człowiekowi możliwości eutanazji nie oznacza wcale obligacji takiego postępowania. Zwolennicy eutanazji wskazują również, iż argumentu „równi pochyłej” nie da się empirycznie udowodnić. Takiemu związkowi przyczynowo-skutkowemu zdają się przeczyć badania przeprowadzone w drugiej połowie lat dziewięćdziesiątych w Holandii i w Stanach Zjednoczonych na temat ,szarej strefy” eutanazji. Jakoś powszechne dopuszczenie dobrowolnej eutanazji biernej i pośredniej w tych państwach, nie stanowiło owego pierwszego kroku do zalegalizowania innych form zachowań eutanatycznych. Zupełnie nieadekwatne jest również powoływanie się przy argumencie z „równi pochyłej” na doświadczenia hitlerowskich Niemiec ${ }^{37}$.

\section{ARGUMENTACJA RELIGIJNA}

Innym typem argumentów, z jakimi możemy się spotkać $\mathrm{w}$ debacie na temat eutanazji, są argumenty religijne. Wydaje się, iż mają one charakter wiążący tylko dla jej wyznawców, albowiem odwołują się do norm religijnych. Przez normę religijną rozumiemy taką, która odnosi się do kultu i praktyk religijnych. Mimo to istnieją normy, które nie mają charakteru wyłącznie religijnego, ale są jedynie uznane przez autorytet danej religii. Najlepszym przykładem jest norma „nie zabijaj”, na powszechność której wskazuje Powszechna deklaracja praw człowieka. W przypadku tej normy uznanie jej za obwiązującą w obrębie danej religii niczego jej merytorycznie nie dodaje. Przywołanie kontekstu religijnego wiąże się najwyżej z dodatkowym uzasadnieniem normy czy też z dodatkową motywacją do jej respektowania $^{38}$. Życie jest darem Bożej miłości. Odniesienie to stanowi też podstawową przesłankę oceny eutanazji zawartej w Deklaracji o eutanazji wydanej w 1980 roku przez Kongregację Nauki Wiary ${ }^{39}$. Zakładając taką koncepcję życia, trudno się dziwić kategorycznemu przesłaniu moralnemu tego dokumentu. Dokument co prawda podkreśla, że świadoma prośba o śmierć jest czymś złym, ale jednocześnie okazuje pełne zrozumienie dla tych, którzy na skutek długich cierpień o tę śmierć proszą. Deklaracja nie jest tak bezduszna, jak twierdzą przeciwnicy eutanazji ${ }^{40}$. Kościół katolicki ma prawo przedstawiać swoją ocenę problemu, podobnie jak czynią to kategorycznie

\footnotetext{
${ }^{37}$ Por. T. Pietrzyk owski, Spór o eutanazję, dz. cyt., s. 116-121.

${ }^{38}$ Por. B. Chyrowicz, Eutanazja i spór o argumenty, dz. cyt., s. 168-169.

${ }^{39}$ Por. Kongregacja Nauki Wiary, Deklaracja o eutanazji, „Acta Apostolicae Sedis” 72(1980), s. 544.

${ }^{40}$ Por. J. Hołówka, Pochwała eutanazji, w: Eutanazja: Prawo do życia - prawo do wolności, red. B. Chyrowicz, Lublin 2005, s. 140.
} 
zwolennicy eutanazji. Niemniej jednak teologiczna refleksja nie może pominąć wyjaśnienia, dlaczego z faktu, iż Bóg jest Panem ludzkiego losu miałaby wynikać niemożliwość odebrania sobie przez człowiek życia. W tym kontekście wiele do zrobienia mają teologowie i bibliści, którzy w celu jednoznacznego odczytania moralnego przesłania Kościoła na temat wartości życia w sposób szczególny winni rzetelnie wyjaśnić starotestamentalne passusy wskazujące na ewidentne naruszenie przez Boga tej normy. Częste przywoływanie teologicznych przesłanek w filozoficznej debacie na temat eutanazji, zdaniem B. Chyrowicz, nie jest czymś dziwnym. Problem eutanazji odsłania bowiem zależność przyjmowanych rozstrzygnięć od założonej wizji tego, kim jest człowiek i jakie jest jego ostateczne przeznaczenie. Etyka wprawdzie uzasadnia zło aktów zabijania, ale nie jest w stanie do końca wyjaśnić sensu cierpienia. Powinniśmy więc być świadomi jej ograniczeń. W tej kwestii religia może mieć coś więcej do powiedzenia ${ }^{41}$.

\section{ARGUMENT ODWOŁUJĄCY SIĘ DO SPOŁECZNYCH OPINII}

W dyskusjach na temat prawa do życia i śmierci, pojawia się także inny argument opierający się na społecznych opiniach. Według niego zamiast upierać się przeciw eutanazji lepiej zalegalizować taką jej formę, która będzie w pełni respektowała autonomię zainteresowanych i eliminowała eutanatyczne podziemie. Zwolennicy takiej argumentacji tłumaczą, że w demokratycznym państwie stanowienie przepisów prawa pozytywnego nie jest równoznaczne z wytyczaniem porządku moralnego.

Wydaje się, że argumentacja etyczna nie powinna ulegać tym społecznym presjom. W tym celu należy rozróżnić dwie płaszczyzny: rosnące poparcie dla eutanazji oraz jej ocenę. Zwyczaje i obyczaje to jedno, a normy to drugie. Zwyczaje się zmieniają, są kwestią umowną. W etyce nie ma miejsca na rewolucję wartości i norm. Poszukiwanie prawdy wiąże się z poszukiwaniem słusznej, tj. obiektywnej oceny czynu. Wobec tego nieraz za słuszne trzeba uznać niepopularne tezy, odrzucając przy tym wszelki subiektywizm i relatywizm moralny. Choć może nieraz to uparte trwanie przy normach, których społeczność nie respektuje, może wydawać się naiwne, to jednak czymś gorszym byłaby pewnego rodzaju uległość wobec społecznych zwyczajów. To podporządkowanie się dyktatowi społeczności, która często działa pod przemożnym wpływem politycznych nacisków, mody, bieżących wydarzeń, z całą pewnością oznaczałoby rezygnacją $\mathrm{z}$ racjonalnego myślenia. Oczywiście etyk nie powinien bagatelizować społecznych opinii. Jednocześnie nie może jednak zdradzać „,racji”, jeśli potrafi je wskazać i uzasadnić. Spór o moralną dopuszczalność eutanazji winien być sporem o rację, nie o opinię ${ }^{42}$.

\footnotetext{
${ }^{41}$ Por. B. Chyrowicz, Eutanazja i spór o argumenty, dz. cyt., s. 170.

${ }^{42}$ Por. tamże, s. 171-172.
} 


\section{ZAKOŃCZENIE}

Jak wynika z powyższych rozważań, postawy etyczne przyjmowane wobec zagadnienia eutanazji są różnorodne i oparte na rozmaitych doktrynach filozoficznych oraz teologicznych. Ich przedstawiciele powołują się na całą gamę argumentów potwierdzających ich stanowisko, a negujących stanowisko przeciwnika. Nie dziwi fakt, że dyskusje na temat eutanazji są silnie nasycone emocjonalnie, albowiem chodzi o rzecz fundamentalną - o ludzkie życie. Niemniej jednak zwolennicy eutanazji nie twierdzą, że ludzkie życie nie jest wartością. Nie godzą się jedynie na tezę, że jest taką wartością w całej rozciągłości (niezależnie od czasu jego trwania i kondycji psychofizycznej, niezależnie od tego, co o jego wartości sądzi w danej chwili zainteresowany). W związku z tym przeciwnicy eutanazji, chcąc prowadzić racjonalny dyskurs, winni nie tyle ulegać emocjom, ile starać się rzetelnie uzasadnić swoje tezy. Rzecz nie w tym, czy odwołamy się do kategorii wartości, czy świętości życia, ale w tym, czy tę wartość rzeczywiście rozpoznajemy. D. von Hildebrand podkreślał, że szansa na respektowanie wartości nie tkwi tylko w znajomości teorii - potrzebne jest bowiem odczytanie wartości i odpowiedź na wezwanie ${ }^{43}$. Jeśli domagamy się poszanowania wartości, zobowiązani jesteśmy tę powinność uzasadnić. B. Chyrowicz nie sądzi jednak, by etyka mogła dostarczyć nam czegoś w rodzaju oczywistego dowodu na wartość życia. Jak niełatwe jest to zadanie, pokazuje fakt, iż dopiero w 1948 roku po Chrystusie uchwalona została Powszechna deklaracja praw czlowieka stwierdzająca, że każdy człowiek ma prawo do życia. Owo „każdy" okazało się trudne do odczytania nawet w chrześcijańskim kręgu. Ograniczenie normy „nie zabijaj” w przypadku eutanazji sprowadza się ostatecznie do postawienia wartości autonomii ponad wartość życia ${ }^{44}$.

Odpowiadając na zawarte w tytule zagadnienie, trzeba stwierdzić, iż eutanazja jest moralnie czymś niedopuszczalnym, albowiem nie jest najlepszym wyjściem z sytuacji. Co więcej, jest złem, gdyż jest zabójstwem, celowym pozbawieniem życia człowieka. W związku z tym rodzi się wątpliwość: Czy w tym kontekście medycznym istnieją działania, które nie mają charakteru eutanatycznego?

Nie ulega wątpliwości, że cierpienie jest złem. Wykluczanie eutanazji nie wyklucza dokładnie wszystkich starań, by uśmierzyć ból i to nawet wówczas, gdy silna dawka leku przeciwbólowego może przyśpieszyć śmierć. W uzasadnieniu takich działań tradycyjna etyka odwołuje się do zasady podwójnego skutku. Jeśli lekarz ma na uwadze uśmierzenie bólu, nie poda pacjentowi dawki wprost letalnej. Gdyby lekarz podał dawkę znacznie większą niż wymaga tego uśmierzenie bólu, czyn może być zakwalifikowany jako eutanazja.

\footnotetext{
${ }^{43}$ Por. tamże, s. 165.

${ }^{44}$ Por. tamże, s. 166-167.
} 
Jak długo jednak dawka jest adekwatna względem słusznego celu (uśmierzenie bólu), działanie może w pełni zostać usprawiedliwione ${ }^{45}$.

Eutanazją nie jest też rezygnacja z terapii w sytuacji, gdy dalsze leczenie pacjenta jest niemożliwe (terapia paliatywna). Prof. J. Hołówka klasyfikuje tego rodzaju sytuacje jako eutanazję bierną ${ }^{46}$. B. Chyrowicz rezerwuje ten termin dla innych sytuacji ${ }^{47}$.

Eutanazją nie będzie też niepodejmowanie w ogóle terapii, gdy chory nie ma żadnych szans na przeżycie. W takiej sytuacji lekarz winien stosować zasadę, w myśl której powinność leczenia jest proporcjonalna do możliwości terapeutycznych ${ }^{48}$.

Eutanatycznego charakteru nie będą miały działania podejmowane w okolicznościach, w których jedyną szansą na uratowanie pacjentowi życia byłaby kosztowna, nowa i ryzykowna terapia. W tym momencie pacjent ma prawo do zrezygnowania z poddania się nadzwyczajnym procedurom medycznym ${ }^{49}$.

Debaty, które ostatnio prowadzone są w polskich mediach, wskazują na to, że temat eutanazji będzie coraz częściej gościł w naszym kraju. W tej bowiem sprawie ostateczna decyzja, niezależnie od wszelkiej argumentacji moralnej, przywoływanych racji etycznych i pragmatycznych, odwoływać się musi do najbardziej elementarnych wyborów aksjologicznych i najgłębszych indywidualnych przekonań o sensie życia, wolności i godności człowieka. Jak nie trudno zauważyć, „tak” dla eutanazji może pojawić się na gruncie określonej antropologii. Wprowadzenie pomysłu rozwiązania za pomocą eutanazji różnych dramatycznych problemów chorych jest możliwe tam, gdzie uwierzono, że są okoliczności, w których nie warto żyć. W takiej sytuacji ignoruje się akceptację niepowtarzalnego istnienia konkretnego człowieka i skupia się na stanie, w jakim jest chory. Stan ten jest uciążliwy zarówno dla chorego, jak i dla najbliższych oraz dla szpitalnego personelu. Proponuje się więc „zabicie z miłosierdzia”. Uważa się to za akt humanitaryzmu służący likwidacji cierpienia. Nie zauważa się jednak, że wraz z likwidowaniem niepotrzebnego cierpienia likwiduje się samego człowieka. W argumentacji tej ujawnia się nihilizm, w którym brakuje odkrycia wartości istnienia każdej niepowtarzalnej osoby ludzkiej. Takie stanowisko da się wythumaczyć na gruncie koncepcji utylitarystyczno-hedonistycznej. Nie widać natomiast miejsca dla eutanazji, nawet w samej tylko teorii - tam, gdzie w człowieku widzi się osobę, tam gdzie każde istnienie jest czymś niepowtarzalnym i wartościowym. Jeśli bowiem człowiek jest osobą, to sens jego życia przekracza wszelkie dostępne miary i nie można go mierzyć poprzez straty ani korzyści społeczne.

\footnotetext{
${ }^{45}$ Por. B. Chyrowicz, Eutanazja i spór o argumenty, dz. cyt., s. 155.

${ }^{46}$ Por. J. Hołówka, Pochwała eutanazji, dz. cyt., s. 131.

${ }^{47}$ Por. B. Chyrowicz, Eutanazja i spór o argumenty, dz. cyt., s. 156.

${ }^{48}$ Por. tamże.

${ }^{49}$ Por. tamże.
} 


\title{
EUTHANASIA AND THE RIGHT TO LIFE. \\ A PHILOSOPHICAL DISPUTE ON THE SCOPE OF VALIDITY \\ OF THE NORM "YOU SHALL NOT KILL"
}

\begin{abstract}
Summary
This article bears a polemical character. Apart from the arguments for euthanasia, the reader will have an opportunity to get acquainted also with the arguments against considering euthanasia as morally justified. The ethical debate on the problem euthanasia should exhibit characteristics of a controversy over arguments. However, rejection of euthanasia does not mean undertaking all the possible efforts that aim at prolonging human life. There are situations in which a doctor must take a dramatic decision not to start a therapy or decision to abandon it, limiting his intervention to alleviating the patient's pain.
\end{abstract}

\section{Keywords:}

euthanasia, right to die, passive euthanasia, active euthanasia 
